\title{
PENGARUH PEMBERIAN EKSTRAK KUNYIT TERHADAP GAMBARAN HISTOPATOLOGI AORTA TIKUS WISTAR (rattus novergicus) HIPERLIPIDEMIA
}

\author{
${ }^{1}$ Anggelina Thendry \\ ${ }^{2}$ Lily L. Loho \\ ${ }^{2}$ Poppy M. Lintong \\ ${ }^{1}$ Kandidat Skripsi Fakultas Kedokteran Universitas Sam Ratulangi \\ ${ }^{-2}$ Bagian Patologi Anatomi, Fakultas Kedokteran Universitas Sam Ratulangi Manado \\ Email: athendry11_017@ymail.com
}

\begin{abstract}
Atherosclerosis is a chronic inflammatory process that can be triggered by one of the risk factors of hyperlipidemia. This research was conducted to see the aorta associated with the provision of margarine that induce hyperlipidemia and administration of curcumin turmericcontaining compounds that act as antioxidants and anti-inflammatory. This research is experimental. The purpose of this study to determine the effect of extract of turmericon Wistar rat aorta histopathology induced hyperlipidemia with margarine. This study used 20 Wistar rats were divided into 5 groups, each group consisting of 4 rats. Group A (negative control group) is given only standard pellets, group B (positive control group) was given margarine 5gr/head /dayfor 28 days, group C was given margarine $5 \mathrm{gr} /$ head /day for 28 days followed by administration of standard pellets for 7 day, group D given margarine $5 \mathrm{gr} / \mathrm{head} /$ day for 28 days followed by administration of turmeric extract $50 \mathrm{mg} / \mathrm{head} / \mathrm{day}$ for 7 days, and group $\mathrm{E}$ are given margarine $5 \mathrm{gr} / \mathrm{head} /$ day along with turmeric extract $50 \mathrm{mg} / \mathrm{head} /$ dayfor 28days. The results shows that microscopically visible aortic wall with foam cells in the tunica intima and tunica media in the positive control group and the administration of $50 \mathrm{mg}$ of turmeric extract reduced foam cells. Conclusion: Turmeric extract showed foam cells in the intima and media less than that of margarine.
\end{abstract}

Keywords: hyperlipidemia,turmeric, margarine, aorta histopathology

\begin{abstract}
Aterosklerosis adalah proses radang kronik yang dapat dicetuskan oleh salah satu faktor resiko hiperlipidemia. Penelitian ini dilakukan untuk melihat pembuluh darah aorta berhubungan dengan pemberian margarin yang menginduksi hyperlipidemia dan pemberian kunyit yang mengandung senyawa kurkumin yang berperan sebagai antioksidan dan anti inflamasi. Penelitian ini bersifat eksperimental.Tujuan penelitian ini untuk mengetahui pengaruh pemberian ekstrak kunyit terhadap gambaran histopatologi aortatikus wistar hiperlipidemia yang diinduksi dengan margarin. Penelitian ini menggunakan 20 ekor tikus wistar yang dibagi ke dalam 5 kelompok yang masingmasing kelompok terdiri dari 4 ekor tikus. Kelompok A(kelompok kontrol negatif) hanya diberikan pelet standar, kelompok B(kelompok kontrol positif) diberikan margarin 5gr/ekor/hari selama 28 hari, kelompok C diberikan margarin 5gr/ekor/hari selama 28 hari kemudian dilanjutkan dengan pemberian pelet standar selama 7 hari, kelompok D diberikan margarin 5gr/ekor/hari selama 28 hari kemudian dilanjutkan dengan pemberian ekstrak kunyit 50mg/ekor/hari selama 7 hari, dan kelompok E yang diberikan margarin 5gr/ekor/hari bersamaan dengan pemberian ekstrak kunyit 50mg/ekor/hari selama 28 hari. Secara mikroskopik tampak dinding aorta dengan sel-sel busa pada tunika intima dan tunika media pada kelompok kontrol positif dan pada pemberian ekstrak kunyit 50 mg sel busa berkurang. Simpulan: Pemberian ekstrak kunyit menunjukan sel-sel busa pada tunika intima dan media lebih sedikit dibandingkan dengan pemberian margarin.
\end{abstract}

Kata kunci: hiperlipidemia, kunyit, margarin, istopatologi aorta 
Hiperlipidemia ditandai dengan peningkatan kadar lipid dalam darah dan merupakan salah satu faktor resiko terjadinya aterosklerosis. ${ }^{1}$ Hiperlipidemia kronis dapat menyebabkan disfungsi endotel. Hiperlipidemia dipengaruhi oleh asupan makanan sehari-hari. ${ }^{2}$ Salah satu bahan makanan yang dapat meningkatkan kadar kolesterol terutama kolesterol low density lipoprotein (LDL) adalah margarin.Margarin mengandung banyak asam lemak trans. Asam lemak transdapat menyebabkan terjadinya peningkatan kadar kolestrol LDL darah. ${ }^{3}$ Peningkatan permeabilitas pembuluh darah karena disfungsi endotel menyebabkan LDL lebih mudah masuk ke dinding pembuluh darah. Keadaan stres oksidatif menyebabkan LDL lebih mudah mengalami oksidasi menjadi LDL-ox yang kemudian akan ditelan oleh makrophag scavenge receptorsehingga terbentuk sel busa. Penimbunan LDL pada dinding pembuluh darah dapat membentuk bercak ateroma. $^{1,4}$

Antioksidan dapat menghambat oksidasi molekul dan radikal bebas.Penggunaan antioksidan banyak diteliti saat ini, salah satunya adalah kurkumin. ${ }^{4}$ Kurkumin merupakan salah satu senyawa yang diisolasi dari tanaman Curcuma sp dan pemberi warna kuning pada tanaman kunyit Curcuma longa L. Kunyit banyak digunakan sebagai rempahrempah dan pemberi warna pada makanan dan tekstil. Secara tradisional kunyit digunakan dalam pengobatan berbagai penyakit seperti anoreksia, batuk, diabetes, hepatitis, rematik dan sinusitis. ${ }^{5}$ Beberapa penelitian menunjukan bahwa kunyit memiliki potensi sebagai anti inflamasi dan antioksidan. $^{4}$

Tujuan penelitian ini adalah untuk mengetahui pengaruh pemberian ekstrak kunyit terhadap gambaran histopatologi aorta tikus wistar yang diberi margarin untuk menginduksi terjadinya hiperlipidemia.

\section{METODE PENELITIAN}

Penelitian ini merupakan penelitian eksperimental laboratorik yang dilakukan di Laboratorium Patologi Anatomi Fakultas Kedokteran Universitas Sam Ratulangi Manado selama 5 bulan, sejak bulan September 2014sampai Januari 2015. Subyek penelitian adalah dua puluh ekor tikus wistar dewasa, yang terdiri dari tikus kontrol negatif (4 ekor) dan tikus perlakuan (16 ekor).

Hewan uji berjumlah dua puluh ekor wistar yang dibagi menjadi lima kelompok perlakuan. Kelompok A, terdiri atas empat ekor wistar yang tidak diberikan perlakuan sebagai kelompok negatif yang hanya diberikan makan pelet biasa (pakan standar) selama 28 hari, kemudian diteriminasi. Sebelum diterminasi, dilakukan penimbangan berat badan dan pengukuran kolesterol darah.Kelompok B, terdiri atas empat ekor wistar yang diberikan margarin 5gr/hari selama 28 hari sebagai kontrol positif. ${ }^{6}$ Margarin dipanaskan sampai mencair kemudian didinginkan dan diberikan dengan menggunakan disposibel $1 \mathrm{ml}$ yang ujungnya disambung dengan sonde, dan tikus terlebih dahulu dipuasakan. ${ }^{3}$ Sebelum diterminasi, dilakukan penimbangan berat badan dan pengukuran kolesterol darah.Kelompok C, terdiri atas empat ekor wistar yang diberikan margarin5gr/hari selama 28 hari, kemudian dilanjutkan dengan pemberian pelet selama 7 hari. Sebelum diterminasi, dilakukan penimbangan berat badan dan pengukuran kolesterol darah.Kelompok D, terdiri atas empat ekor wistar yang diberikan margarin 5gr/hari selama 28 hari pertama dan dilanjutkan dengan pemberian ekstrak kunyit 50 mg/hari selama 7 hari. ${ }^{7}$ Ekstrak kunyit dicampur dengan aquades sebanyak $1 \mathrm{ml}$ dan diberikan dengan menggunakan disposable $1 \mathrm{ml}$ yang ujungnya disambungkan dengan sonde, dan tikus terlebih dahulu dipuasakan. Sebelum diterminasi, dilakukan penimbangan berat badan dan pengukuran kolesterol darah.Kelompok E, terdiri atas empat ekor wistar yang diberikan margarin 5gr/hari bersama-sama dengan pemberian ekstrak kunyit 50 mg/hari selama 28 hari. Sebelum diterminasi, dilakukan penimbangan berat 
badan dan pengukuran kolesterol darah.

Penelitian ini dilaksanakan selama 35

hari. Terminasi dilakukan pada semua hewan uji dari masing-masing kelompok untuk diambil jantung serta aortanya. Pengukuran kadar kolesterol darah dilakukan sebelum perlakuan dengan cara mengambil darah tepi tikus wistar. Darah tepi diambil dengan cara membuat luka pada ujung ekor tikus wistar, kemudian darahnya diteteskan pada stik alat periksa kolesterol NESCO. Setelah perlakuan, pemeriksaan kolesterol tikus wistar dilakukan dengan cara mengambil darah dari jantung sebanyak $3 \mathrm{ml}$ setelah terlebih dahulu tikus diinjeksi dengan lidokain.

Penimbangan berat badan dilakukan sebelum perlakuan pada minggu pertama (hari-1), akhir minggu kedua dan pada hari terakhir (hari ke-28 dan hari ke-35), sebelum semua kelompok perlakuan dan kontrol diterminasi.

\section{HASIL PENELITIAN}

Pengukuran berat badan

Pengukuran berat badan tikus wistar dilakukan sebelum perlakuan dan sesudah perlakuan dengan menggunakan timbangan gram, sehingga diperoleh persen rata-rata pertambahan berat badan tikus wistar (Tabel 1).

Pengukuran Kadar Kolesterol

Sebelum penelitian, dilakukan pengukuran awal kadar kolesterol total darah tikus wistar dan hasil analisa dengan menggunakan alat ukur kolesterol NESCO diperoleh rata-rata pengukuran kadar kolesterol total yang normal (Tabel 2). Setelah lima minggu perlakuan, dilakukan pengukuran profil lipid (Tabel 2) dan diperoleh rata-rata kadar kolesterol total, kadar LDL, kadar HDL, dan kadar trigliserida.
Tabel 1. Pengukuran Berat Badan

$$
\text { Berat Badan (gram) }
$$

\begin{tabular}{cccc}
\cline { 2 - 4 } Kel & $\begin{array}{c}\text { Sebelum } \\
\text { Perlakuan }\end{array}$ & $\begin{array}{c}\text { Sesudah } \\
\text { Perlakuan }\end{array}$ & $\begin{array}{c}\text { Pertambahan } \\
(\%)\end{array}$ \\
\hline A & 242.5 & 240 & $-0.01 \%$ \\
\hline B & 232.5 & 285 & $0.22 \%$ \\
\hline C & 230 & 212.5 & $-0.07 \%$ \\
\hline D & 243.3 & 230 & $-0.05 \%$ \\
\hline E & 246.6 & 263.3 & $0.06 \%$ \\
\hline
\end{tabular}

Tabel 2. Rata-rata Kadar Kolesterol Total

$\begin{array}{cc}\text { Kelompok } & \text { Mean }(\mathrm{mg} / \mathrm{dl}) \\ \text { A } & 134.25 \\ \text { B } & 169.25 \\ \text { C } & 155.75 \\ \text { D } & 156.3 \\ \text { E } & 155.3\end{array}$

Tabel 3. Rata-rata Profil Lipid

\begin{tabular}{ccccc}
\hline \multirow{2}{*}{ Kel } & \multicolumn{4}{c}{ Rata-rata Profil lipid (mg/dl) } \\
\cline { 2 - 5 } & $\begin{array}{c}\text { Kolesterol } \\
\text { total }\end{array}$ & LDL & HDL & Trig \\
\hline A & 61.25 & 16.25 & 43.25 & 28 \\
\hline B & 73.25 & 16.25 & 53 & 30.5 \\
\hline C & 58.5 & 8.7 & 47.25 & 113.25 \\
\hline D & 69.6 & 15.65 & 48.3 & 75.3 \\
\hline
\end{tabular}

\section{Gambaran Mikroskopik Aorta Tikus Wistar}

1. Kelompok A

Gambaran mikroskopik pada kelompok A menunjukan lapisan aorta yang nomal, pada tunika intima maupun tunika media pada aorta tikus wistar (Gambar 1).

Gambar 1. Gambaran mikroskopik potongan melintang aorta tikus wistar

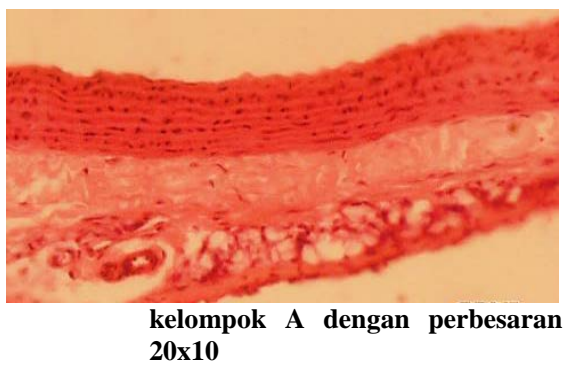

2. Kelompok B

Gambaran mikroskopik aorta tikus wistar pada kelompok A menunjukan adanya makrofag berfoam (sel busa) yang banyak, 
yang terlihat pada tunika intima dan tunika media (Gambar 2 dan Gambar 3).

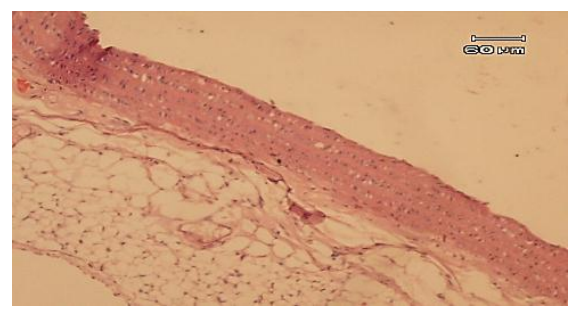

Gambar 2. Gambaran mikroskopik aorta tikus wistar kelompok B potongan melintang dengan perbesaran $20 \times 10$

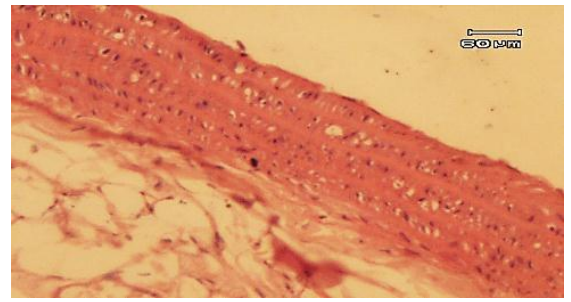

Gambar 3. Gambaran mikroskopik aorta tikus wistar kelompok B potongan melintang dengan perbesaran 40x10. Terlihat adanya makrofag berfoam (panah kuning) pada tunika intima dan tunika media.

3. Kelompok C

Pada kelompok dengan pemberian margarin selama 28 hari dan dilanjutkan pelet selama 7 hari, menunjukan banyak sel-sel busa, yang terlihat pada tunika intima dan tunika media aorta (Gambar 4).

Gambar 4. Gambaran mikroskopik aorta tikus wistar kelompok $C$ potongan melintang dengan perbesaran 20x10. Terlihat adanya makrofag berfoam (panah kuning) pada tunika intima dan tunika media.

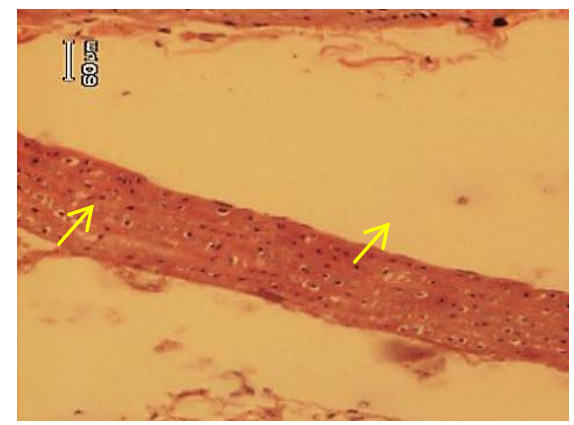

4. Kelompok D

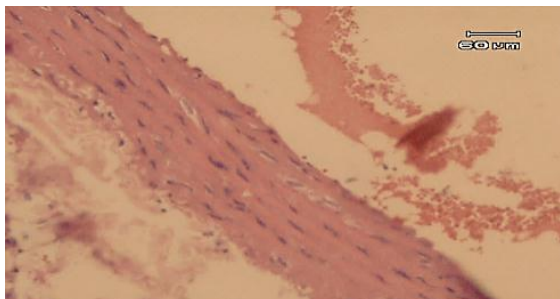

Pada kelompok tikus wistar dengan pemberian margarin selama 28 hari dan dilanjutkan dengan pemberian, ekstrak kunyit selama 7 hari, menunjukan gambaran mikroskopik aorta tampak sel-sel busa, namun dalam jumlah yang sedikit (Gambar 5) dan dibeberapa bagian menunjukan gambaran mikroskopik aorta yang normal (Gambar 6).

Gambar 5. Gambaran mikroskopik aorta tikus wistar kelompok D potongan melintang dengan perbesaran $20 x 10$. Terlihat adanya makrofag berfoam (panah kuning) pada tunika intima dan tunika media dalam jumlah yang sedikit.

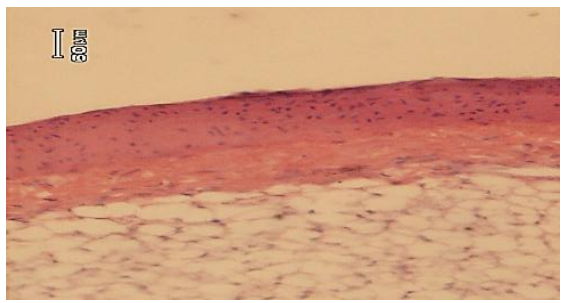

Gambar 6. Gambaran mikroskopik aorta tikus wistar kelompok D potongan melintang dengan perbesaran 20x10. Tidak terlihat adanya sel busa pada tunika intima dan tunika media.

5. Kelompok E

Gambaran mikroskopik aorta tikus wistar yang diberikan margarin bersamaan dengan ekstrak kunyit selama 28 hari, menunjukan lapisan aorta yang normal (Gambar 7). 


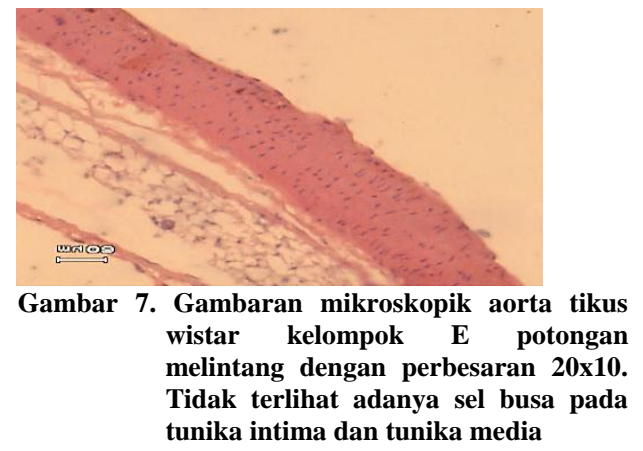

\section{BAHASAN}

Pada tikus perlakuan kontrol positif (kelompok B) dengan pemberian margarin selama 28 hari dapat dilihat adanya sel-sel busa pada tunika intima dan tunika media aorta. Hal ini sesuai dengan kepustakaan yang menyebutkan bahwa sel busa dapat terbentuk pada hiperlipidemia kronis. Pada hiperlipidemia kronis terjadi penumpukan LDL, yang dapat teroksidasi oleh karena pengaruh dari radikal bebas yang mendeaktivasi nitrat oksida. LDL yang teroksidasi ini, ditelan oleh makrofag melalui scavenger receptor, sehingga terbentuk sel busa. ${ }^{1,8,9}$ Pada pengukuran berat badan kolesterol total, kelompok B mengalami kenaikan berat badan dan kolesterol total tertinggi. Kenaikan ini disebabkan oleh karena konsumsi margarin secara terus menerus sesuai dengan teori yang menyebutkan bahwa konsumsi lemak yang berlebihan dapat meningkatkan berat badan dan kadar kolesterol. ${ }^{10}$

Kelompok perlakuan dengan pemberian margarin selama 28 hari dan dilanjutkan dengan pelet standar selama 7 hari (Kelompok C) menunjukkan sel-sel busa pada tunika intima dan tunika mediaaorta. Hal ini sesuai dengan kepustakaan yang mengatakan bahwa dengan mengurangi asupan, terutama makanan kolesterol tinggi (makanan yang tinggi lemak) dapat menurunkan kadar kolesterol dan berat badan. Namun, dengan mengurangi asupan saja tidak cukup untuk menurunkan kadar kolesterol yang tinggi. ${ }^{10}$

Pada kelompok tikus D yang diberi perlakuan margarin selama 28 hari kemudian dilanjutkan dengan pemberian ekstrak kunyit menunjukkan gambaran mikroskopik aorta yang masih terdapat selsel busa, namun dalam jumlah yang sedikit dan beberapa bagian menunjukkan lapisan aorta yang normal. Hal ini dibuktikan dengan pemberian ekstrak kunyit selama 7 hari setelah pemberian margarin dihentikan. Sesuai dengan penelitian yang dilakukan sebelumnya bahwa kurkumin sebagai salah satu senyawa yang terkandungdalam kunyit memiliki potensi sebagai antioksidan. Kurkumin memiliki grup fungsional seperti kelompok $\beta$-diketo, ikatan karbon rangkap dan cincin fenil yang mengandung sejumlah substien hidroksil dan metoksil. Melalui strukturnya ini, kurkumin dapat menangkap ROS (reactive oxygen species) berlebihan yang menjadi penyebab utama terjadinya stress oksidatif. ${ }^{4}$ Selain itu, sebagai antioksidan, kurkumin mampu menurunkan oksidasi LDL yang berperan penting terhadap pembentukan foam cell. Kurkumin juga merupakan anti inflamasi. Kurkumin mampu melakukan down regulasi faktor transkrip seperti faktor reseptor $\mathrm{NF}_{-\mathrm{K}} \mathrm{B}$ dan activator protein 1 (AP-1). Faktor transkrip AP-1 bertindak mengatur ekspresi berbagai macam sel yang penting untuk ploriferasi, diferensiasi dan apoptosis sel. Oleh karena itu, kurkumin dapat menekan proses inflamasi pada pembuluh darah sehingga menurunkan ekpresi molekul adhesi dan sitokin yang dapat mempermudah pembentukan plak pada dinding pembuluh darah. ${ }^{4,11,12}$

Pada kelompok E yang diberikan margarin dan ekstrak kunyit secara bersamaan selama 28 hari menunjukkan gambaran mikroskopik aorta yang normal, dimana tidak terdapatnya sel-sel busa pada tunika intima dan tunika media. Hal ini sesuai dengan yang didapatkan pada beberapa penelitian yang dilakukan sebelumnya, dimana ekstrak kunyit yang mengandung kurkumin yang berpotensi sebagai antioksidan melindungi membran endotel dari peroksidasi lipid. Peroksidasi lipid dapat menyebabkan kerusakan membran sel melalui radikal bebas dan kurkumin menghambat peroksidasi terutama melalui scavenging radikal bebas 
Thendry, Loho, Lintong: Pengaruh pemberian ekstrak kunyit...

dengan menjaga keseimbangan superoksida dismutase, katalase dan glutation peroksidase. $^{13}$

\section{SIMPULAN}

1. Pemberian margarin pada tikus menyebabkan hiperlipidemia dan secara mikroskopik terlihat sel busa pada tunika inima dan media aorta.

2. Pemberiann ektrak kunyit menurunkan kadar kolesterol darah dan secara mikroskopik sel busa berkurang pada tunika intima dan media pembuluh darah aorta.

\section{SARAN}

1. Perlu dilakukan penelitian mengenai berbagai dosis pemberian ekstrak kunyit untuk melihat dosis yang paling tepat.

2. Perlu dilakukan penelitian dengan waktu penelitian yang lebih lama dan jumlah sampel yang lebih besar untuk hasil yang lebih bermakna secara statistik.

3. Perlu dilakukan perhitungan tebal dinding aorta pada beberapa tempat.

\section{DAFTAR PUSTAKA}

1. Kumar, Cotran, Robbins. 2015. Robbins and Cotran Pathologic Basis of Disease Ninth Edition. Elsevier Saunders

2. Kasron. 2012. Kelainan dan Penyakit Jantung: Pencegahan serta pengobatannya. Yogyakarta: Nuha Medika;202-04.

3. Octifani S. Pengaruh Pemberian Margarin Terhadap Rasio Kolesterol LDL/HDL Tikus Sprague Dawley. Semarang: Universitas Diponegoro. 2012;4-5.

4. Nurtamin T. Potensi Kurkumin untuk
Mencegah Aterosklerosis. Countinuing Professional Development. 2014;8:633-35.

5. Shishodia S, Amin HM, Lai R, Aggarwal BB. Curcumin inhibits constitutive NF$\mathrm{kB}$ activation, induces G1/S arrest, suppresses ploriferation, and induces apoptosis in mantle cell lymphoma. Biochemical Pharmacology. 2005;70:700-13

6. Sumual G. Gambaran Histopatologi Aorta Tikus Wistar Yang Diberikan Ekstrak Kayu Manis Paska Diinduksi Margarin. FK UNSRAT. 2012:20-21

7. Dalimarta Setiawan. Kunyit dalam: Atlas Tumbuhan Obat Indonesia, jilid 6 . Jakarta: Pustaka Bunda. 2009. h. 83

8. Mitchell RN, Schoen FJ. Blood Vessels. Dalam: Kumar, Abbas, Fausto, Aster. Robbins and Cotran Phatologic Basis of Disease. $8^{\text {th }}$ ed. Elsevier Saunders, 2010.

9. Papodi NN. Pengaruh Ekstrak Daun Gedi (Abelmoschus manihot L.) Terhadap Gambaran Histopatologi Aorta Tikus Wistar Dengan Diet Aterogenik. FK UNSRAT. 2012:10

10. Davey P. 2005. At a Glance Medicine. Jakarta: Erlangga. h.141

11. Nobuhiro $Y$. Atherosclerosis and Oxidative Stress. JMAJ. 2001;4(12):529-34

12. Mahfous MM, Zhou SQ, Kummerow FA. Curcumin prevents the oxidation and lipid modification of LDL and its inhibition of prostacyclin generation by endothelial cells in culture. Prostaglandins others lipid mediat. 2009;90(1-2):13-20

13. Menon VP, Sudher AR. Antioxidant and Antinflamatory propertien of curcumin. Adv Exp Med Biol. 2007;595:105-25 